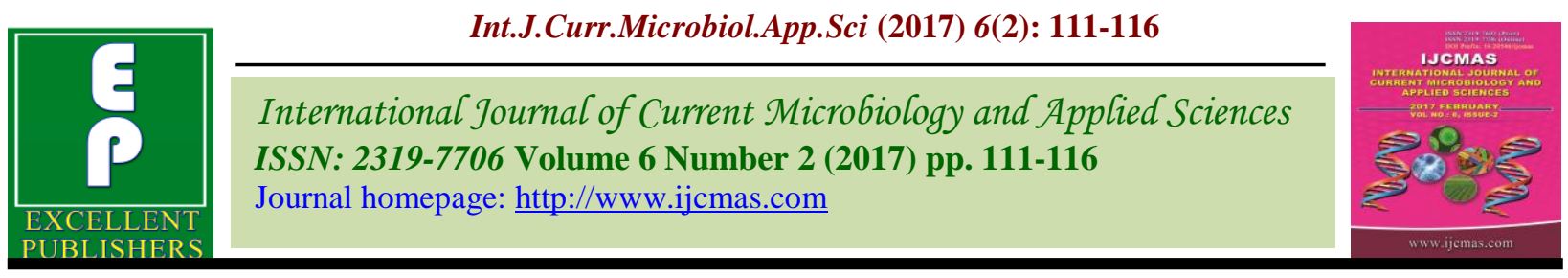

Original Research Article

http://dx.doi.org/10.20546/ijcmas.2017.602.016

\title{
New Record of Chagunius chagunio (Cypriniformes: Cyprinidae) from Kangsabati reservoir, West Bengal, India
}

\author{
V. Kumar*, Lianthuamluaia, U.K. Sarkar, C.M. Roshith, D. Panda, K.M. Sandhya, \\ S. Kumari, P. Mishal, A. Roychowdhury and G. Karnatak
}

ICAR-Central Inland Fisheries Research Institute (CIFRI), Barrackpore, Kolkata-700120, India

*Corresponding author

\section{A B S T R A C T}

Keywords

Chagunius

chagunio,

Kangsabati

reservoir, New

record.

Article Info

Accepted:

05 January 2017

Available Online:

10 February 2017
Chagunius chagunio (Hamilton, 1822) was described based on specimens collected from Kangsabati reservoir, Damodar Basin, West Bengal. The species is described as a species of Chagunius with body elongated depth more than its head; mouth narrow and subterminal, barbels 2 pairs, longer than orbit; dorsal spine osseous, strong and recurved, its length is rather more than that of head, excluding the mouth; dorsal fin commences midway between the end of the snout and the base of caudal fin; scales small; lateral line complete and lateral line with 46 scales. Chagunius chagunio is described as a new record based on these collected specimens.

\section{Introduction}

Chagunius chagunio was first described by Hamilton (1822) as Cyprinus chagunio from the river Yamuna and the northern rivers of Bihar and Bengal. Hora (1928) also described it under the same genus Cyprinus (Linnaeus, 1758). Later, Day (1878) placed the species under the genus Barbus (Cuvier). Subsequently, Smith (1945) placed it under the genus Chagunius (Smith, 1938). Day (1878), in his survey on the Ichthyo-fauna of India, observed that the distribution of $C$. chagunio (Hamilton) was restricted to Orissa, Bengal, Assam, Bihar and north western provinces to the Punjab, but not reported from Sindh, the Deccan, Western coast, Mysore, Madras and Burma.
Shaw and Shebbeare (1937), was in agreement with Day (1878) the regarding distribution of the species. Tilak and Sarma (1982) reported the species from the rivers of North and East India, Pakistan and Thailand. A subsequent survey by Sen (1985) revealed that the fish has a wide distribution in India, in Assam, all along the Himalayas, and in Burma and Thailand. Talwar and Jhingran (1991) reported the species from the Brahmaputra and Ganga drainages all along the Himalayan foot-hills. Recently, Jayaram (1999) reported that the fish is widely distributed in North India along the base of Himalaya, South central Asia, Bangladesh, Myanmar, Nepal, Pakistan and Thailand. As 
per IUCN (2010) status this fish species has been categorized as of least concern (LC) (Vishwanath 2010) but in the near future it is likely that over exploitation and habitat destruction may pose major threat to its fishery. The Kangsabati reservoir in West Bengal, India, under Damodar basin is connected with the Ganga River system. Its icthyofaunal diversity is poorly explored till date. Collections from the exploratory survey conducted under the present study from this reservoir include a new record of Chagunius chagunio.

\section{Materials and Methods}

Specimens of Chagunius chagunio $(\mathrm{n}=3)$ (Image 1 (A, B)) locally called as patharchatta were collected from Kangsabati reservoir $\left(23^{\circ} 02^{\prime} 31.8^{\prime \prime N}, 8^{\circ} 43^{\prime} 33.6^{\prime E}\right.$ ) (Figure 1) by using cast net during October 2015. Measurements were made point to point on the left side of specimens wherever possible with dial calipers to the nearest $0.1 \mathrm{~mm}$. The colour in fresh specimens was noted before fixation and preservation in 10\% formalin (Kumar and Hassan 2015). Counts and measurements follow Kottelat (1990) and lateral line scale count, Kottelat (2001). Head length (HL) and anatomical measurements are expressed as proportions of standard length (SL) and subunits of head as proportions of head length (HL) (Dishma and Vishwanath, 2012). Vertebral counts follow Weitzman (1962). Fin rays were counted under a stereozoom light microscope.

\section{Results and Discussion}

\section{Description}

Body elongated its depth more than its head. Mouth narrow and subterminal, barbels 2 pairs, longer than orbit. Suborbital region, cheeks and anterior superior margin of the orbit is covered with numerous pores. Dorsal spine osseous, strong and recurved, its length is rather more than that of head, excluding the mouth. Dorsal fin commences midway between the end of the snout and the base of caudal fin. Scales small; lateral line complete; lateral line with 46 scales; 6 scale rows between lateral line and pelvic fin; 15 rows before the dorsal fin.

D I 8; P iii 12; V ii 8; A ii 6; C 22; L. 146

The morphometric details of the specimen i.e., total length, standard length, body depth, length of the snout, fork length, body depth, post orbital length of head, etc. are given in Table 1. In all the biometric characters, body proportions and colour pattern, the specimen agrees with the description given by Hamilton (1822); Talwar and Jhingran (1991).

\section{Colour}

Body is silvery with a pinkish tinge. Caudal fin with blackish tip; in young middle third of caudal fin orange; tipped with black.

\section{Habitat and ecology}

Chagunius species inhabit high land rivers and tributaries containing clear water and substrates of rock, gravel and/or sand. They have been recorded in areas of rapids as well as sections with moderate current and patches of aquatic vegetation. Juveniles are found in the main channels, as opposed to backwater habitats, but they show a preference for slightly calmer water than adults (Rainboth 1986).

The Kangsabati reservoir is a tributary of Damodar River and which is a part of Ganga River system. The sampling site is located around $50 \mathrm{~km}$ away from the Bankura district $\left(23^{\circ} 02^{\prime} 31.8^{\prime \prime} \mathrm{N}, \quad 86^{\circ} 43^{\prime} 33.6^{\prime \prime} \mathrm{E}\right)$ of West Bengal. The average physico-chemical properties of the sampling site was $\mathrm{pH}-7.87$, depth- $2.83 \mathrm{~m}$, transparency- $127.7 \mathrm{~cm}$, water temperature- $23{ }^{\circ} \mathrm{C}$, dissolved oxygen- 6.8 and specific conductivity- $158.4 \mu \mathrm{s} / \mathrm{cm}$. 


\section{Distribution}

Chagunius chagunio is distributed in the Ganga and Brahmaputra drainages of northern and north-eastern India, Nepal and Bangladesh. The distribution is also reported in the Himalayan foothills. Talwar and Jhingran (1991) reported that $C$. chagunio is generally found in large rivers characterized by rocky bottom, clear and fast water, and little or no vegetation.

Table.1 Morphometric characters for Chagunius chagunio

\begin{tabular}{lll}
\hline Morphometric data & Range & Mean \\
\hline Total length (mm) & $162.1-168.3$ & 165.2 \\
Standard length (mm) & $127.9-132.7$ & 130.3 \\
In \% of standard length & & \\
Body depth at dorsal fin origin & $27.44-27.73$ & 27.59 \\
Head length & $25.80-26.01$ & 25.91 \\
Body width (anal origin) & $7.35-7.76$ & 7.56 \\
Body width (dorsal origin) & $15.64-15.75$ & 15.69 \\
Caudal peduncle length & $18.84-19.07$ & 18.95 \\
Caudal peduncle depth or height & $11.88-12.28$ & 12.08 \\
Caudal fin length (upper lobe) & $26.74-26.83$ & 26.78 \\
Caudal fin length (lower lobe) & $25.88-26.22$ & 26.05 \\
Dorsal fin base length & $18.92-19.22$ & 19.07 \\
Predorsal length & $46.99-46.19$ & 46.59 \\
Dorsal fin height & $22.91-23.06$ & 22.98 \\
Dorsal spine length & $21.97-22.16$ & 22.06 \\
Pectoral fin length & $20.48-20.12$ & 20.30 \\
Prepectoral length & $25.18-25.24$ & 25.21 \\
Pectoral fin base length & $5.47-5.88$ & 5.68 \\
Ventral fin length & $19.08-19.29$ & 19.18 \\
Preventral length & $50.20-50.41$ & 50.30 \\
Ventral fin base length & $6.25-6.63$ & 6.44 \\
Anal fin length & $20.41-20.87$ & 20.64 \\
Preanal length & $74.43-75.28$ & 74.86 \\
Anal fin base length & $10.24-10.47$ & 10.36 \\
In \% of head length & & \\
Snout length & $37.27-37.37$ & 37.32 \\
Eye diameter & $24.24-24.33$ & 24.29 \\
Head depth at eye & $67.27-67.50$ & 67.38 \\
Head width (max.) & $60.30-60.54$ & 60.42 \\
Head width (eye) & $45.76-46.06$ & 45.91 \\
Length of barbel (lower) & $23.64-23.75$ & 23.70 \\
Length of barbel (upper) & $18.48-18.54$ & 18.51 \\
\hline
\end{tabular}


Fig.1 Map showing locality of Chagunius chagunio indicated as a star

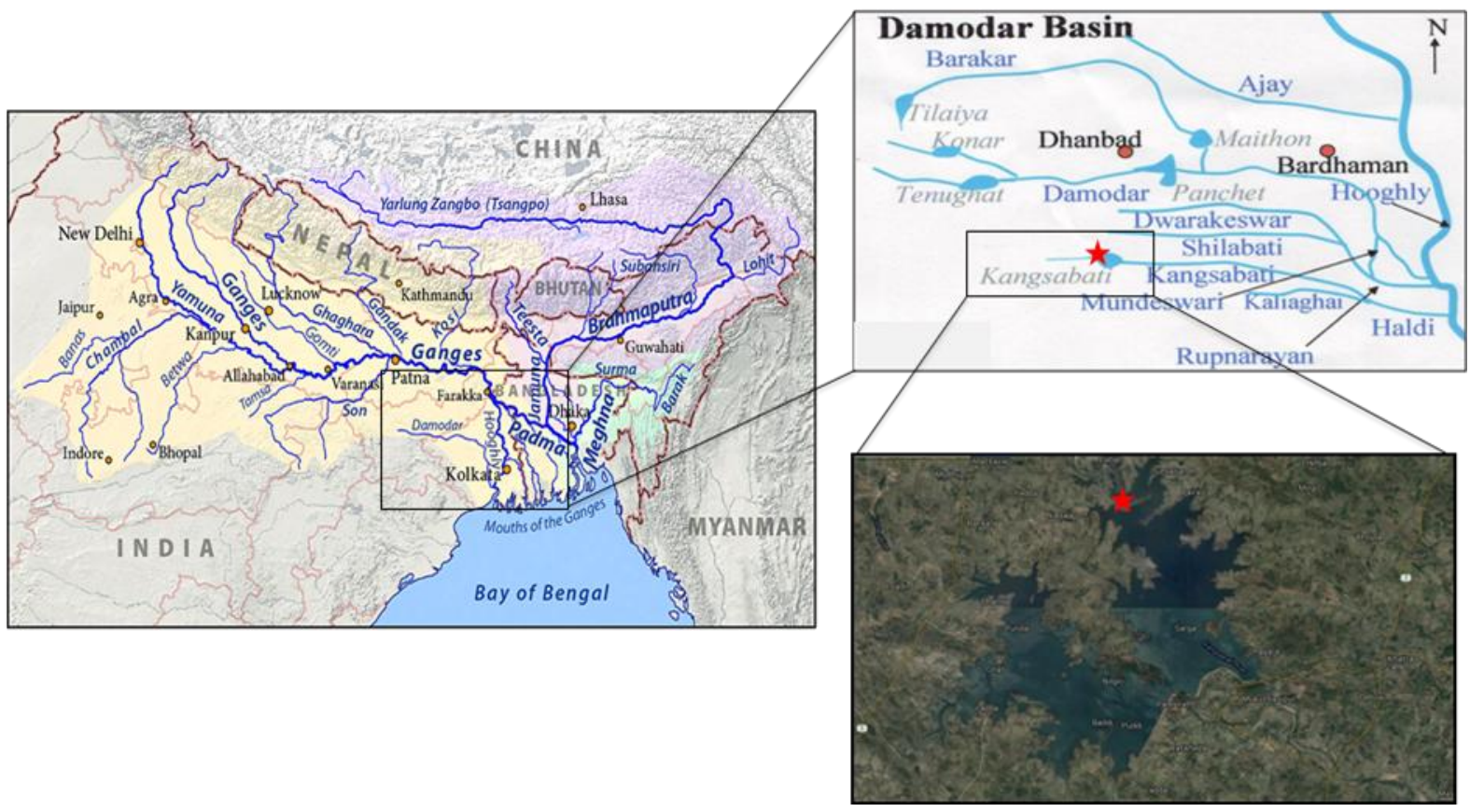

Image.1 (A, B) Chagunius chagunio, side view, 127.9 mm SL

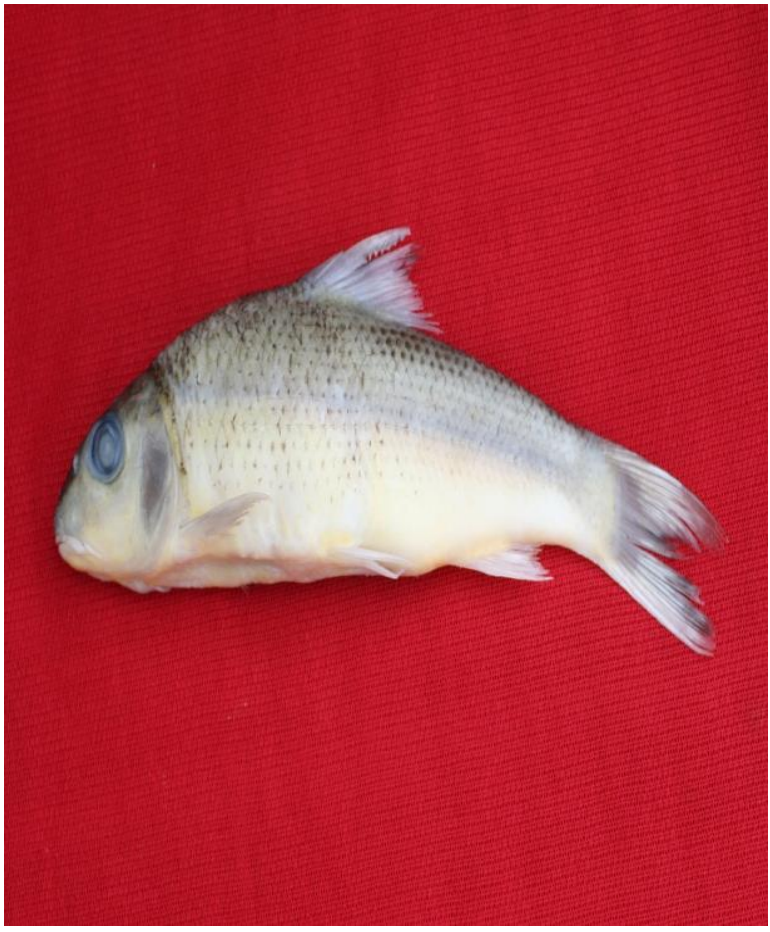

Adults are found in habitats with stronger current than juveniles prefer. The fish is not known to be a good range migrant and its

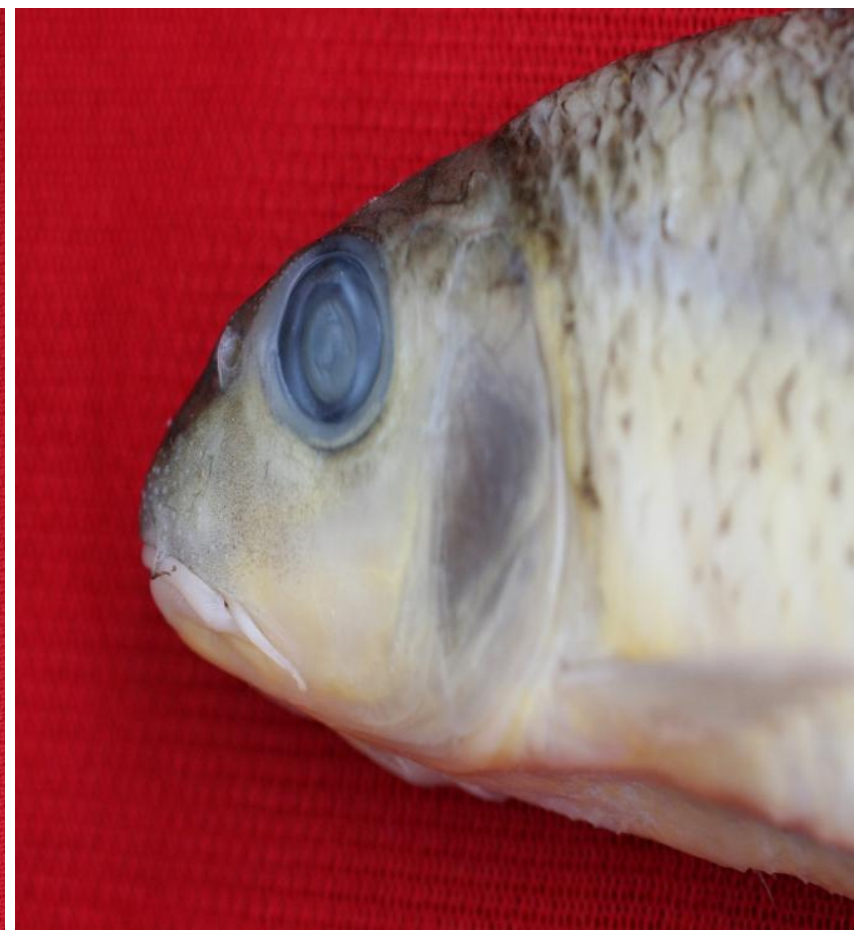

movements are fairly restricted. It attains a maximum length of about half a meter and reaches maturity at a size of $20-25 \mathrm{~cm}$. The 
fish offers a good sport. This is a new distribution record from Kangsabati reservoir from Ganga River system, India.

The name of the genus Chagunius was first given by Smith (1945) and the species $C$. chagunio was described by HamiltonBucchanon (1822) as Cyprinus chagunio. As reported by Day (1878), Shaw and Shbbeare (1937), Hora and Gupta (1940), Srivastava (1968), Menon (1974), Talwar and Jhingran (1991) and Jayaram (1999), the fish $C$. chagunio is distributed in the Brahmaputra and Ganga drainages along northern India and the north western provinces to Punjab and even in Pakistan, Bangladesh, Burma, Nepal and Thailand, but it is not reported from the Deccan, the Western Coast, Karnataka and Tamil Nadu.

Workers like Day (1878), Hora and Gupta (1940), Menon (1974) and Talwar and Jhingran (1991) described the species with body depth slightly more than head length; mouth narrow and subterminal; 2 pairs barbels, longer than orbit; eye-diameter 5 to 6.5 times in head; dorsal spine strong and serrated, the denticles strong and recurved; scales small, transverse scale-rows 11/9, circumferential scales 40-44; dorsal spine osseous, strong and recurved, its length is rather more than that of head; scales small; lateral line complete; lateral line with 46 scales. The diagnostic features (Table-1) distinctly show that the species under report, C. chagunio could be readily separated from all the reported species as well as the synonymies of the Genus Chagunius and have been found to be similar when compared with already reported specimens. $C$. chagunio was one of the common species caught in the Kangsabati reservoir during the monsoon. It is esteemed in the region for its taste and highly priced. The fish migrates upstream from April to July and return from August to November. In other seasons, it was not present, as reported by fisherman.
The new record of $C$. chagunio from Kangsabati reservoir, West Bengal, India, under Damodar basin, Ganga River system has thrown a new light on the distribution of the species in the lower stretches unlike its restricted distribution to the upper stretches of Himalayan Rivers as reported earlier. However, further studies are needed to determine the habitat preference, feeding habit and reproductive behaviour of the species so that any variability of the reported species could be further observed, if any.

\section{Acknowledgement}

Authors are thankful to Director ICARCentral Inland Fisheries Research Institute (CIFRI) and other technical and supporting staff for the Financial and technical support.

\section{References}

Day, F. 1878. Fishes of India, London, Wiliams and Norgate. PI 136, fig.l and pi 140 , fig. 2,559 p.

Dishma, M. and Vishwanath, W. 2012. Barilius profundus, a new cyprinid fish (Teleostei: Cyprinidae) from the Koladyne basin, India. J. Threatened Taxa, 4(2), pp.2363-2369.

Hamilton, F. An account of the fishes found in the river Ganges and its branches. Edinburg: Printed for Archibald Constable and Company, 1822. vol. 1, ivii + 1-405, Pls. 1-39.

Hora, S.L. and Gupta, J.C. 1940. On a Collection of Fish from Kalimpong Duars and Siliguri Terai, northern Bengal. J Royal Asiatic Soc. Bengal Sci., 7(8): 77-83.

Hora, S.L. 1928. Remarks on Gunther-Day controversy regarding the specific validity of Hamilton-Buchanan's Cyprinius chagunio. J. Proc. Asiat. Soc. Beng., (N.S.), 23(3): 415-417.

Jayaram, K.C. 1999. The freshwater fishes of 
the Indian region. Delhi. Narendra Publishing House. 551 p.

Kottelat, M. 1990. Indochinese Nemacheilines, A Revision of Nemacheiline Loaches (Pisces: Cypriniformes) of Thailand, Burma, Laos, Cambodia and southern Vietnam. Verlag, Dr. Friedrich Pfiel, Munchen, $262 \mathrm{pp}$.

Kottelat, M. 2001. Fishes of Laos. Wildlife Heritage Trust, Colombo, $198 \mathrm{pp}$.

Kumar, V. and Hassan, M.A. 2015. Methods and procedures of sampling, preservation and identification for fish taxonomy studies. World J. Fish and Marine Sci., 7(2): 105-108.

Menon, A.G.K. 1974. A check list of fishes of the Himalayan and the Indo-Gangetic plains. Spl. Publ. No. 1. Inland Fisheries Soc. India, Barrackpore, 83-84 p.

Rainboth, W.J. 1986. Fishes of the Asian Cyprinid Genus Chagunius. Occasional Papers of the Museum of Zoology University of Michigan 712: 1-17.

Sen, T.K. 1985. Fish fauna of Assam. Rec. Zoo. Survey o f India. O.C.C. paper. No.64, Fig. 19, 43-35 Pp.
Shaw, G.E., Shebbeare, E.O. 1937: The fishes of northern Bengal. J. Roy. Asia Soci. Bengal. Sci., V-IH, Fig.31. 35-36 p.

Smith, H.M. 1945. The fresh water fishes of Siam or Thailand Bull. U.S. Nat. Mus., No. 188: 622 p.

Srivastava, G.J. 1968. Fishes of Eastern Uttar Pradesh. Vashwa Vidyalaya Prakashan, Varanasi, India.

Talwar, P.K. and Jhingran A.G. 1991. Inland fishes of India and Adjacent Countries-Vol. 1 \& 2. A.A. Balkema, Rotterdam, 541.

Tilak, R., Sarma, U. 1982. Game fishes of India and angling. International Book Distributors, Dehragun, India. Fig.33, 92-94 p.

Vishwanath, W. 2010. Chagunius chagunio. The IUCN Red List of Threatened Species: Version 2013.1. <www.iucnred list.org>. Downloaded on 22 February 2016.

Weitzman, S.H. 1962. The osteology of Brycon meeki, a generalized Characid fish, with an osteological definition of the family. Standford Ichthyol. Bull., 8(1): 1-77.

\section{How to cite this article:}

Kumar, V., Lianthuamluaia, U.K. Sarkar, C.M. Roshith, D. Panda, K.M.S. Sandhya, S. Kumari, P. Mishal, A. Roychowdhury and Karnatak, G. 2017. New Record of Chagunius chagunio (Cypriniformes: Cyprinidae) from Kangsabati reservoir, West Bengal, India. Int.J.Curr.Microbiol.App.Sci. 6(2): 111-116. doi: http://dx.doi.org/10.20546/ijcmas.2017.602.016 